This item was submitted to Loughborough's Research Repository by the author.

Items in Figshare are protected by copyright, with all rights reserved, unless otherwise indicated.

\title{
Adhesion requirements for photovoltaic modules of polymeric encapsulation
}

PLEASE CITE THE PUBLISHED VERSION

http://dx.doi.org/10.1109/IRPS.2016.7574636

PUBLISHER

(c) IEEE

VERSION

AM (Accepted Manuscript)

LICENCE

CC BY-NC-ND 4.0

\section{REPOSITORY RECORD}

Zhu, Jiang, Gabriel Surier, Dan Wu, Daniel Montiel-Chicharro, Thomas R. Betts, and Ralph Gottschalg. 2019. "Adhesion Requirements for Photovoltaic Modules of Polymeric Encapsulation". figshare.

https://hdl.handle.net/2134/23285. 


\title{
Adhesion Requirements for Photovoltaic Modules of Polymeric Encapsulation
}

\author{
Jiang Zhu, Gabriel Surier, Dan Wu, Daniel Montiel-Chicharro, Thomas R. Betts, Ralph Gottschalg \\ Centre for Renewable Energy Systems Technology, Wolfson School of Mechanic, Electrical and Manufacturing Engineering, \\ Loughborough University \\ Loughborough, Leicestershire, LE11 3TU, United Kingdom \\ phone: +44 (0)1509 635313, e-mail: j.zhu@lboro.ac.uk
}

\begin{abstract}
Adhesion requirements for PV are often discussed but a detailed quantification based on scientific principles is outstanding. A test for the realistic assessment of requirements is presented. The difference between this test and the conventional peel test is that the test is conducted in-situ during ageing experiments in the climatic cabinet at realistic operating temperatures. Weights are attached to the backsheet of tested PV mini-modules to test stability of adhesion as devices being aged. This test is designed to identify the weakest interface of the multilayer encapsulation system and investigate the difference between field tests and failures (not) observed in certification testing. A series of samples was prepared under a wide range of lamination conditions. Different failure modes and ageing characteristics were observed. Some samples suffered quick failure of the adhesive bonds in the encapsulation system while others withstood forces of $20 \mathrm{~g} / \mathrm{cm}$ for 1000 hours. The test allows a clear discrimination between different samples and links closely to operational requirements.
\end{abstract}

Index Terms-Adhesion, Ageing, Encapsulation, Lamination, Photovoltaic

\section{INTRODUCTION}

The reliability and durability of PV modules is the key to the financial success of any PV systems. PV modules rely on packaging materials to provide extended protection for solar cells and electrical circuitry against various operating environments in order to maintain long service life [1]. Typical module packaging materials for c-Si modules, as shown in Fig. 1, include a front glass layer, two layers of encapsulant which sandwich the active materials, and a polymeric layer of backsheet. These are laminated and framed to form a PV module. The different layers form adhesive bonds with each other during lamination. The quality of encapsulation depends on the adhesion at the interfaces, which may also be potential degradation pathways for moisture ingress [2], [3]. Delamination can occur at these interfaces, as well as cohesively. This will enable further moisture ingress into module [4], [5] and may result in corrosion of solar cells, cell fingers, busbars and interconnects, leading to power losses [6], [7]. Delamination is also a major safety risk, which may damage the integrity of the module or lead to the electrical part of module being exposed to ambient surroundings. Delamination is a major reason of field failures as e.g. a statistic by SolarWorld shows that over $90 \%$ of the returned modules have delamination related failures [8]. These failures are apparently not being picked up in the process design. This could be due to the current test for adhesion of laminates not being sufficient or the requirements not being set appropriately. The state of the art is a peel test of as-produced modules carried out after exposure to environmental stresses, which is not very realistic and field failures will be different.

This work focusses on the adhesion requirement and developing an appropriate test. Failures of packaging material at interfaces of glass to encapsulant, encapsulant to backsheet and backsheet sub layers will be investigated as these are the commonly observed failures of fielded PV modules [9]-[13]. Lamination conditions have a significant impact on the adhesion stability and failure modes [14], as will be demonstrated in this paper.

Adhesion deterioration and failure of packaging materials is one of the crucial ageing mechanisms for PV modules. However, up to now, there is no definition of how to test adhesion and how much adhesion is required for PV modules in any of the international standards. In the PV community, the peel test is widely used to characterize interfacial adhesions between rigid front sheet (e.g. glass) and encapsulant (e.g. ethyl vinyl acetate EVA) or flexible backsheet (e.g. multilayer polymeric sheets) and EVA [15], [16]. The test is normally carried out at room condition for samples to investigate the relative change of interfacial adhesion before and after ageing, e.g. the study by $\mathrm{Wu}$ [17], which identified the degradation pattern of peel strength between EVA and backsheet under various damp-heat stresses. The peel test investigates adhesions at the interface of interest, which needs careful preparation of the testing samples. It is impractical to conduct the testing on full module level and therefore testing focuses on material components and is performed on mini-modules or laminates.

The outcomes of adhesion tests depend strongly on testing condition, e.g. temperature, as the elasticity of EVA is temperature dependent [18]. The temperature of PV modules during operation is influenced by ambient temperature, irradiance, and wind-speed. At different sites with different climatic conditions, module temperature can easily reach 65 $85^{\circ} \mathrm{C}$ [19]. This can be verified using empirical models, e.g. [20] for rack-mounted modules in the field. Higher temperatures are expected for roof-mounted modules. Mechanical stresses causing adhesion, e.g. the weight of junction box, unsupported cables or cables being pulled, will 


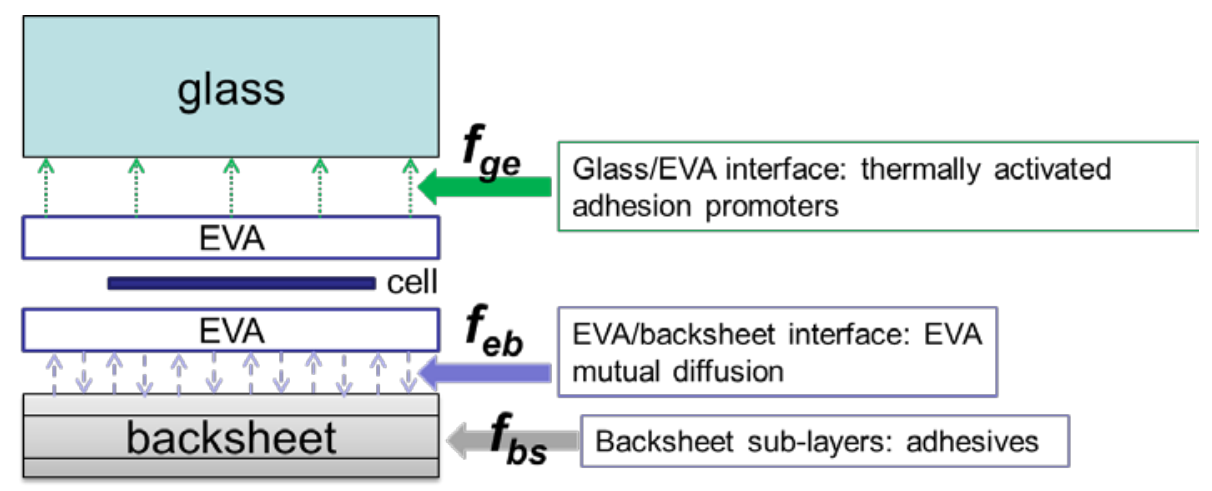

Figure 1. Structure of an EVA-encapsulated PV module and adhesion mechanisms at three interfaces

normally be applied at elevated temperature. This is simulated here with a gravity based test during damp-heat exposure, i.e. attaching weights to modules during slightly modified certification tests. This test will result in delamination failure at samples' weakest interface. The time to delamination is recorded, i.e. the time to failure (TTF). This allows a discrimination between devices and will enable appropriate boundaries to be set for certification testing. The weight attached to the module backsheet ranges from $20 \mathrm{~g} / \mathrm{cm}$ to $1 \mathrm{~kg} / \mathrm{cm}$ in order to identify the response to a range of conditions. The stress levels would represent something like a 'normal' junction box weight to potentially some items being caught on connecting wires.

The following part of this paper presents the proposed testing approach that allows the realistic assessment of adhesion needs for PV modules. The result is compared to that of the conventional peel test performed at room condition. All samples were tested to fail against the damp-heat stress that is considered as a standard stress test for PV module durability.

\section{EXPERIMENTAL APPROACH}

Specific samples were produced for the study reported here. These are mini-modules laminated in-house at CREST. Their size is $12.5 \mathrm{~cm}$ by $20 \mathrm{~cm}$ with a glass-EVA-solar cellEVA-backsheet structure. No frames or sealants are used. All materials are commercially available from PV industry, but details are covered by confidentiality. The glass front layer is $2.9 \mathrm{~mm}$ thick float glass, although this will not change the outcome of the experiment compared to the $3.2 \mathrm{~mm}$ thick standard glass. Standard $460 \mu \mathrm{m}$ fast cure EVA is used as encapsulant. The backsheet is a tri-layer insulating polymer consisting PET/PET/primer layers. The solar cells used are 1.8W mc-Si cells. These mini-modules were prepared under different lamination temperatures at $125^{\circ} \mathrm{C}, 135^{\circ} \mathrm{C}, 140^{\circ} \mathrm{C}$, $145^{\circ} \mathrm{C}$ and $150^{\circ} \mathrm{C}$ with constant curing time of 10 minutes. These samples are referred to in the following as L125, L135, L140, L145 and L150, respectively.

The lamination temperature has significant impacts on the curing of EVA. The curing rate of EVA increases with the increasing temperature. If the temperature is too high, curing may occur too quickly without completely removing the gases within the module structure and the gases generated during crosslinking, resulting in bubbles and potential adhesive issues. Low temperatures may result in incomplete curing.
Optimum curing temperature ensures good crosslinking of the EVA, which then has a better resistivity to moisture ingress. The crosslinking also converts a thermoplastic material into a network format thermosetting material so that the material will not flow under heat. The measured gel content of the L125 samples was around $70 \%$, which was the lowest. The gel content increases with the increasing lamination temperature

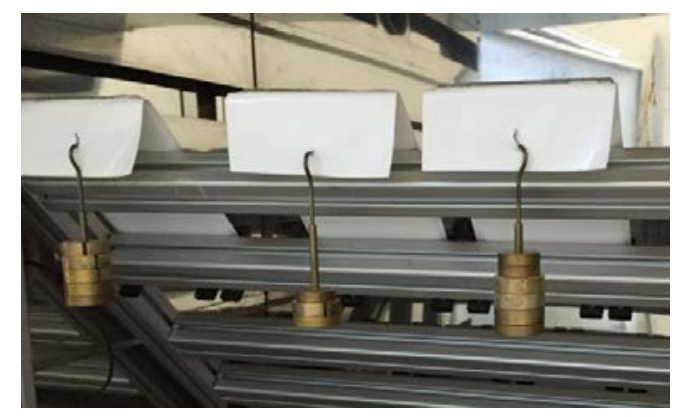

Figure 2. Samples with weight hung from the top part of backsheet.

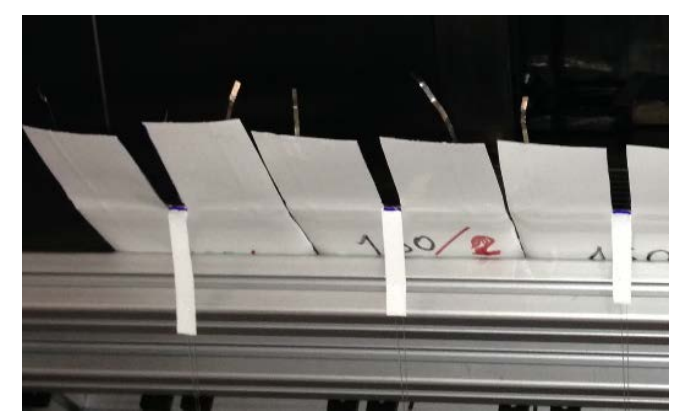

Figure 3. Samples with narrow strips for gravity test.

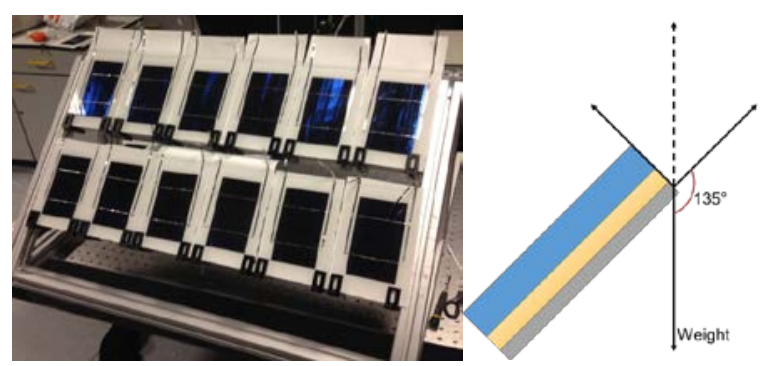

Figure 4. Testing frame for gravity test and its static force analysis 
and reached 91\% for L150 samples. All these samples are within specifications set for acceptable gel contents by the industry [21].

The backsheet of each mini-module was prepared $5 \mathrm{~cm}$ longer than the module's length to enable easy attachment of a weight. The actual weight was hung at the top part of the backsheet as shown in Fig. 2, which applied a mixture of peel and shear force by its gravity. Different weights of $250 \mathrm{~g}, 500 \mathrm{~g}$ and $1 \mathrm{~kg}$ were used. For some samples, the top part of backsheet was cut into narrow strips of $1 \mathrm{~cm}$ or $2 \mathrm{~cm}$ wide for testing as demonstrated in Fig. 3. This initial cut significantly increased the force per unit width, which was expected to lead to different failures. All the samples were mounted on a testing frame with $45^{\circ}$ tilted angle as show in Fig. 4. This setup was then placed in an environmental chamber operating at $85^{\circ} \mathrm{C} / 85 \% \mathrm{RH}$. The test is a $135^{\circ}$ peel test, which is close to conditions seen in the field. All samples were subjected to test to fail, i.e. tested until delamination occurred. The time when the delamination occurred was recorded for each sample and used as an indicator of the quality of module packaging.

The gravity test is to investigate the adhesion failures at the weakest interface of packaging materials under stressed condition that modules may encounter during the operation of their lifetime. The melting point of EVA is around $60-70^{\circ} \mathrm{C}$, which means the EVA may be in different phases under room condition and at $85^{\circ} \mathrm{C}$ [22]. This increases the likelihood of different failures being identified by the two testing approaches. The other difference between these two approaches is that the gravity test is a constant load testing, i.e. peeling at a constant force, whereas the peel test is a constant displacement testing, i.e. peeling at a constant rate. These differences demonstrate that the presented test is closer to realistic conditions than the peel test used in the laboratory. change over time, which led to different failure modes at different stress times. Depending on the weight applied to backsheet, different failure modes were observed.

Fig. 5 shows the observed four different types of failures of module packaging during the gravity test. Type A failure is delamination of backsheet sub-layers. This was observed for samples with weight hung from narrow strips only. Type B failure is delamination at the interface between glass and EVA. Type $C$ failure is delamination at the interface between EVA and backsheet. Type D failure is a mix of Type A and Type B that delamination occurred at multiple layers including backsheet sub-layer and between EVA and glass.

All tested samples delaminated eventually, except for the L140 sample with $20 \mathrm{~g} / \mathrm{cm}$ force which did not fail after 1800 hours exposure. The observed delamination categories are summarized in Table I in dependence of the lamination temperature and weight per centimeter.

\begin{tabular}{|c|c|c|c|c|c|}
\hline & $20 \mathrm{~g} / \mathbf{c m}$ & $\mathbf{4 0 g} / \mathbf{c m}$ & $\mathbf{8 0 g} / \mathbf{c m}$ & $500 \mathrm{~g} / \mathbf{c m}$ & $\mathbf{1 0 0 0 g} / \mathbf{c m}$ \\
\hline $\mathbf{L 1 2 5}$ & $\mathrm{C}$ & $\mathrm{C}$ & $\mathrm{C}$ & $\mathrm{C}$ & $\mathrm{C}$ \\
\hline $\mathbf{L 1 3 5}$ & $\mathrm{A}$ & $\mathrm{A}$ & $\mathrm{B}$ & $\mathrm{AB}$ & $\mathrm{AB}$ \\
\hline $\mathbf{L 1 4 0}$ & - & $\mathrm{A}$ & $\mathrm{B}$ & $\mathrm{A}$ & $\mathrm{A}$ \\
\hline $\mathbf{L 1 4 5}$ & $\mathrm{A}$ & $\mathrm{AB}$ & $\mathrm{B}$ & $\mathrm{A}$ & $\mathrm{A}$ \\
\hline $\mathbf{L 1 5 0}$ & $\mathrm{A}$ & $\mathrm{A}$ & $\mathrm{B}$ & $\mathrm{AB}$ & $\mathrm{AB}$ \\
\hline
\end{tabular}

TABLE I. SUMMARY OF FAILURE CATEGORIES FOR GRAVITY TEST

\section{OBSERVED FAILURES}

The weakest interface of the packaging material could

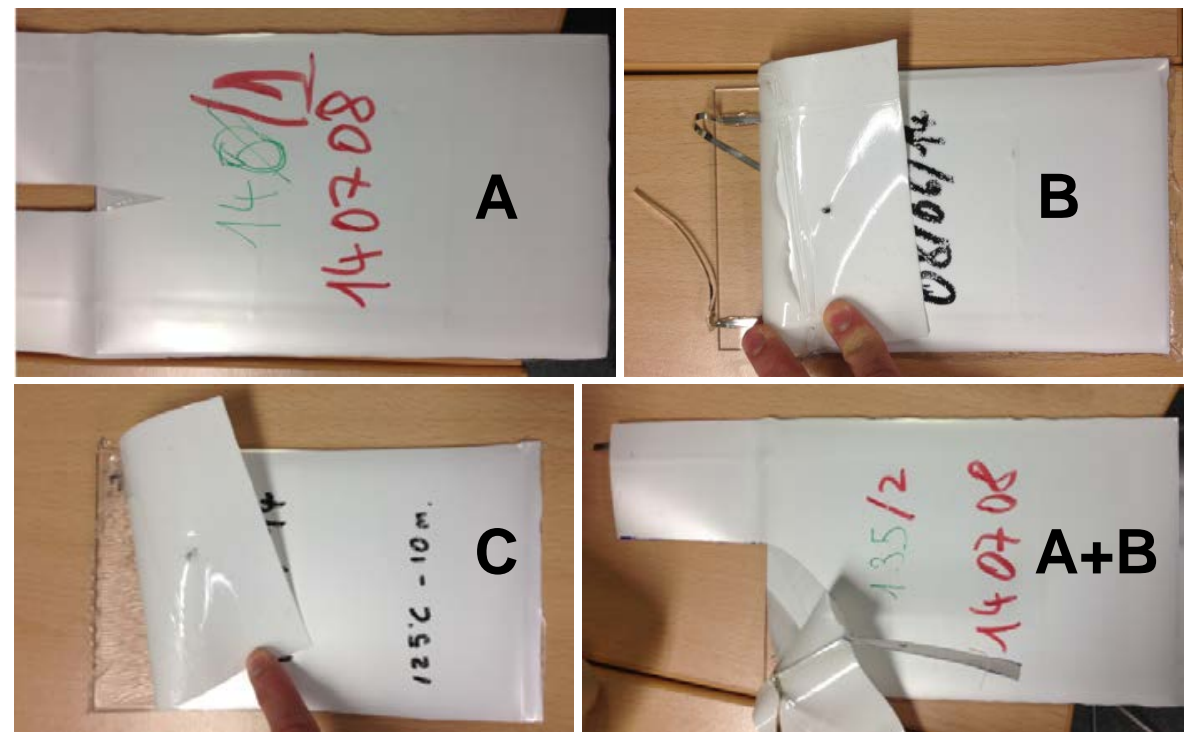

Figure 5. Different types of failures of module packaging during the gravity test. A) delamination of backsheet sub-layers; B) delamination at the interface between glass and EVA; C) delamination at the interface between EVA and backsheet; D) mix of Type A and Type B failures. 


\begin{tabular}{|c|c|c|c|c|c|}
\hline & $\mathbf{2 0 g} / \mathbf{c m}$ & $\mathbf{4 0 g} / \mathbf{c m}$ & $\mathbf{8 0 g} / \mathbf{c m}$ & $\mathbf{5 0 0 g} / \mathbf{c m}$ & $\mathbf{1 0 0 0} / \mathbf{c m}$ \\
\hline $\mathbf{L 1 2 5}$ & 2 & 2 & 2 & 2 & 1 \\
\hline $\mathbf{L 1 3 5}$ & $1000 \pm 100$ & $175 \pm 25$ & 4 & 2 & 2 \\
\hline $\mathbf{L 1 4 0}$ & - & $360 \pm 40$ & $8 \pm 2$ & 2 & 2 \\
\hline $\mathbf{L 1 4 5}$ & $1630 \pm 50$ & $300 \pm 60$ & 2 & 2 & 2 \\
\hline $\mathbf{L 1 5 0}$ & $800 \pm 50$ & $25 \pm 5$ & 3 & 2 & 2 \\
\hline
\end{tabular}

TABLE II. SUMMARY OF DELAMINATION TIME (HOURS)

The samples tested with a weight of $500 \mathrm{~g} / \mathrm{cm}$ or $1000 \mathrm{~g} / \mathrm{cm}$ were the samples with narrow strips of backsheet, as shown in Table I. They all experienced fast delamination within 2 hours, which means the adhesion could not cope with the weights. These forces are also not experienced for prolonged periods in the field, and thus this might be over testing the samples. However, cutting of backsheets also led to different failures modes. The L135 and L150 samples presented a mix of Type A and Type B failures, which indicate that the adhesion at backsheet sub-layers and the adhesion at glass/EVA interface were comparable $\left(\boldsymbol{f}_{\boldsymbol{a} e} \approx \boldsymbol{f}_{\boldsymbol{b s}}\right)$. The L140 and L145 samples, which are around the recommended optimum lamination temperature, saw Type A failure only. This suggests that the adhesion at the interface between glass and EVA was improved and better than that at backsheet sublayers $\left(f_{g e}>f_{b s}\right)$.

It was also found that all of the delaminated samples could cope with the weights applied to them and no obvious delamination was further observed when storing at room temperature.

\section{DElamination Time AND APPlied WeightS}

The observed delamination time for the L125-L150 samples is summarized against the applied weight in Table II. All L125-L150 samples suffered quick failure with weights of $80 \mathrm{~g} / \mathrm{cm}$ and above, which means the adhesion cannot cope with the force. With the decreasing weight to $20 \mathrm{~g} / \mathrm{cm}$, the delamination time increased to over 1000 hours for L135L150 samples, as one could expect. The L140 and L145 samples withstand the applied forces for longer.

The weight of $20 \mathrm{~g} / \mathrm{cm}$ is similar to a junction box of PV module (around $200 \mathrm{~g}, 10 \mathrm{~cm}$ wide). The results presented would be the most relevant to normal field operation. Any additional loading may could be seen as abnormal operation, although it is still an unfortunate practice to lift modules at the cables which will easily exert these forces on the backsheet.

\section{CONCLUSIONS}

An in-chamber gravity test to assess the durability of backsheet adhesion was developed. It was performed at stress condition at $85^{\circ} \mathrm{C} / 85 \% \mathrm{RH}$ and the result was compared to that of the peel strength test conducted at room condition after long term exposure to the same environmental stresses. It is shown

that the test differentiates well between different qualities of lamination.

The absolute minimum force to withstand is the peel strength exerted by the junction box, which is in the order of $20 \mathrm{~g} / \mathrm{cm}$. Traditional tests do not really identify cases that are potential failures in the gravity test. There are some additional loads that may be exerted to stress the durability of backsheets, such as cables dangling off them, cable holders being glued to the back of the module or installers picking up modules by the cables. Clearly modules need to survive these without delamination. Thus limiting the tested force to $20 \mathrm{~g} / \mathrm{cm}$ may be a bit too simplistic and one should potentially allow for $50 \mathrm{~g} / \mathrm{cm}$. However, this limit would give a safety margin but would need to be detailed more by consensus between stakeholders.

The tests demonstrated here were on bespoke samples. The test is just as applicable for large modules where the weights could be attached to the module by gluing them to the back sheets. This should allow to verify high quality lamination during certification testing or ongoing quality assurance during production.

\section{REFERENCES}

[1] A.W. Czanderna, F.J. Pern, "Encapsulation of PV modules using ethylene vinyl acetate copolymer as a pottant: A critical review," Solar Energy Materials and Solar Cells, vol. 43, pp. 101-108, 1996.

[2] G. Oreski, G.M. Wallner, "Delamination behaviour of multi-layer films for PV encapsulation,” Solar Energy Materials and Solar Cells, vol. 89, pp. 139-151, 2005.

[3] G.J. Jorgensen, K.M. Terwilliger, J.A. Del Cueto, S.H. Glick, M.D. Kempe, J.W. Pankow, F.J. Pern, T.J. McMahon, "Moisture transport, adhesion, and corrosion protection of PV module packaging materials," Solar Energy Materials and Solar Cells, vol. 90, pp. 2739-2775, 2006.

[4] M.D. Kempe, "Modeling Rates of Moisture Ingress into Photovoltaic Modules,” Solar Energy Mats. Solar Cells, vol. 90, pp. 2720-2738, 2006.

[5] P. Hülsmann, M. Heck, M. Köhl, "Simulation of water vapor ingress into pv-modules under different climatic conditions," Journal of Materials, vol. 2013, Article ID 102691, 7 pages, 2013.

[6] G. Jorgensen, K. Terwilliger, S. Glick, J. Pern, T. McMahon, "Material testing for PV module encapsulation," NREL/CP-520-33578, May 2003.

[7] E.E. Van Dyk, J.B. Chamel, A.R. Gxasheka, "Investigation of delamination in an edge-defined film-fed growth photovoltaic module," Solar Energy Materials and Solar Cells, vol. 88, pp. 403-411, 2005.

[8] G. Kleiss, J. Kirchner, K. Reichart, Quality and Reliability - sometimes the customer wants more, in Proc. PV Module Reliability Workshop, Golden, USA, 2015.

[9] M.A. Quintana, D.L. King, T.J. McMahon, C.R. Osterwald, "Commonly observed degradation in field-aged photovoltaic modules," in Proc. 29 ${ }^{\text {th }}$ IEEE PVSC, pp.1436,1439, 2002.

[10] W.J. Gambogi, J.G. Kopchick, T.C. Felder, S.W. MacMaster, A.Z. Bradley, B. Hamzavy, E.E.L. Kathmann, T.J. Stika, T.J. Trout, L.G. Garreau-Iles, T. Sample, "Backsheet and Module Durability and Performance and Comparison of Accelerated Testing to Long Term Fielded Modules,” in Proceedings of the 28th European Photovoltaic Solar Energy Conference and Exhibition, pp. 2846-2850.

[11] D. DeGraaff, R. Lacerda, Z. Campeau, "Degradation Mechanisms in Si Module Technologies Observed in the Field; Their Analysis and Statistics," in Proc. PV Module Reliability Workshop, NREL, Denver, Golden, USA, 2011.

[12] P. Sanchez-Friera, M. Piliougine, J. Pelaez, J. Carretero, M. Sidrach de Cardona, "Analysis of degradation mechanisms of crystalline silicon PV modules after 12 years of operation in Southern Europe,” Progress in Photovoltaics: Research and Applications, vol. 19, pp. 658-666, 2011. 
[13] D. Polverini, M. Field, E. Dunlop, W. Zaaiman, "Polycrystalline silicon PV modules performance and degradation over 20 years," Progress in Photovoltaics: Research and Applications, vol. 21, pp. 1004-1015, 2012.

[14] D. Wu, J. Zhu, D. Montiel-Chicharro, T.R. Betts, R. Gottschalg, "Influences of Different Lamination Conditions on the Reliability of Encapsulation of PV Modules," in Proc. 29 $9^{\text {th }}$ European Photovoltaic Solar Energy Conference, pp. 3415 - 3420, 2014.

[15] D.R. Moore, "An introduction to the special issue on peel testing," International Journal of Adhesion and Adhesives, vol. 28, pp. 153-157, 2008.

[16] ASTM Standard Test Method D6862-11 for 90 degree peel resistance of adhesives, 2012.

[17] D.Wu, J. Zhu, T.R. Betts, R. Gottschalg, "Degradation of interfacial adhesion strength within photovoltaic mini-modules during damp-heat exposure,” Prog. Photovolt: Res. Appl., vol. 22, pp. 796-809, 2014.
[18] D.L. King, M.A. Quintana, J.A. Kratochvil, D.E. Ellibee, B.R. Hansen, "Photovoltaic module performance and durability following long-term field exposure,” Prog. Photovolt. Res. Appl., vol. 8, pp. 241-256, 2000.

[19] M. Owen-Bellini, J. Zhu, T.R. Betts, R. Gottschalg, "Environmental Stress Potentials of Different Climatic Regions," in Proc. 31st European PV Solar Energy Conference, pp. 1854 - 1857, 2015.

[20] M.K. Fuentes, "A simplified thermal model for flat-plate photovoltaic arrays,” Sandia report, SAND85-0330, 1987.

[21] A. Preiss, S. Krauter, M. Schoppa, I. Luck, "PV module testing - how to ensure quality after PV module certification," Photovoltaic International, 13th ed., pp. 166-176, August, 2011.

[22] D.C. Miller, M.D. Kempe, S.H. Glick, S.R. Kurtz, "Creep in photovoltaic modules: examining the stability of polymeric materials and components," in Proc. 35 ${ }^{\text {th }}$ IEEE Photovoltaic Specialists Conference, pp. 262-268, 2010 